\title{
Собака в калмыцком и тувинском фольклоре"
}

\author{
Алексей А. Бурыкин, Инджир М. Болдырева, Деляи Н. Музраева \\ Калмыцкий научный центр Российской академии наук, \\ Российская Федерация
}

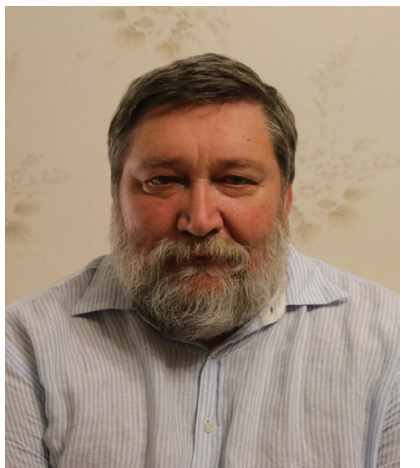

В статье анализируются фольклорные материалы, связанные с собакой, в калмыцкой и тувинской устной традиции. Сравнительное исследование элементов культуры ареально близких народов позволяет при наличии общих базовых элементов общности достраивать общую систему представлений и понятий, формирующих этническую культуру.

Из-за особого очень важного значения собаки в хозяйстве и культуре калмыков и тувинцев дидактический нарратив и прагматика явственно преобладает над общностью сюжетов и мотивов в монгольской традиции (калмыки) и тюркской традиции (тувинцы), несмотря на наблюдаемую общность иных сюжетов и мотивов. Отмечается взаимосвязь образов собаки и волка. Нередки истории, в которых фигурирует пара собак. Священными считаются «четырехглазые» собаки (с пятнами над глазами). Особую роль играют собаки в свадебной обрядности народов.

Материалом исследования явились аудиозаписи 1960-1980-х г2., хранящиеся в На-

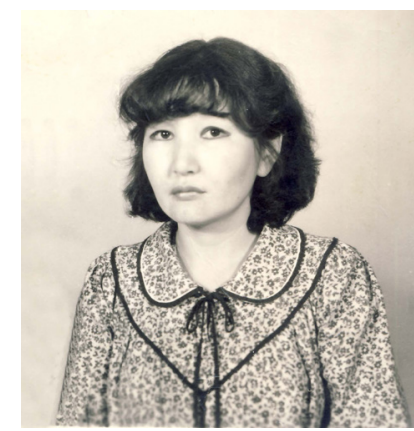
учном архиве Калмыцкого научного цеентра РАН и опубликованные образцы тувинских сказок и эпических жанров.

Ключевые слова: собака; тотемное животное; фольклор; обряды; свадебная обрядность; приметы; целительская способность; калмыки; тувинцы

"Исследование проведено в рамках государственной субсидии - проект «Устное и письменное наследие монгольских народов России, Монголии и Китая: трансграничные традиции и взаи-

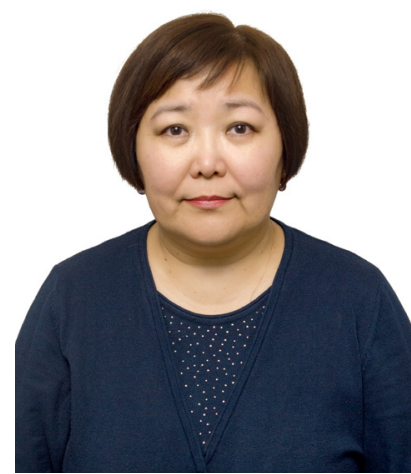
модействия» (регистрационный номер АААA-А19-119011490036-1).

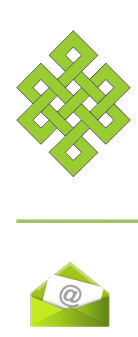

Для цитирования:

Бурыкин А. А., Болдырева И. М., Музраева Д. Н. Собака в калмыцком и тувинском фольклоре [Электронный ресурс] // Новые исследования Тувы. 2019, № 4. URL: https://nit.tuva.asia/nit/article/view/888 (дата обращения: дд.мм.гг.). DOI: 10.25178/ nit.2019.4.10

Бурыкин Алексей Алексеевич - доктор филологических наук, доктор исторических наук, ведущий научный сотрудник отдела монгольской филологии Калмыцкого научного центра РАН. Адрес: 358000, Россия, г. Элиста, ул. И. К. Илишкина, д. 8. Тел.: +7 (911) 709-14-76. Эл. адрес: albury@mail.ru ORCID ID: 0000-0002-9119-2698

Болдырева Инджир Мосиновна - научный сотрудник отдела монгольской филологии Калмыцкого научного центра РАН. Адрес: 358000, Россия, г. Элиста, ул. И. К. Илишкина, д. 8. Тел.: +7 (961) 399-44-08. Эл. адрес: Inzir19@mail.ru ORCIDID:0000-0002-0832-7046

Музраева Деляш Николаевна - кандидат филологических наук, доцент, ведущий научный сотрудник, заведующий отделом монгольской филологии, Калмыцкий научный центр Российской академии наук. Адрес: 358000, Россия, г. Элиста, ул. И. К. Илишкина, д. 8. Тел.: +7 (917) 680-80-21. Эл. адрес: deliash@mail.ru ORCID ID: 0000-0002-8619-9369

Burykin Aleksey Alekseevich, Doctor of Philology, Doctor of History, Leading Research Associate, Department of Mongolian Philology, Kalmyk Scientific Center of the Russian Academy of Sciences. Postal address: 8, Ilishkin St., Elista 358000, Russian Federation. Tel.: +7 (911) 709-14-76.E-mail: albury@mail.ru

Boldyreva Indzhir Mosinovna, Research Associate, Department of Mongolian Folklore, Kalmyk Scientific Center of the Russian Academy of Sciences. Postal address: 8, Ilishkin St., Elista 358000, Russian Federation. Tel.: +7 (961) 399-44-08. E-mail: Inzir19@mail.ru

Muzraeva Delyash Nikolaevna, Candidate of Philology, Leading Research Associate, Head of Department of Mongolian Philology, Kalmyk Scientific Center of the Russian Academy of Sciences. Postal address: 8 Ilishkin St., 358000 Elista, Russian Federation. Tel.: +7 (917) 680-80-21. E-mail: deliash@mail.ru 


\title{
The dog in Kalmyk and Tuvan folklore"
}

\author{
Aleksey A. Burykin, Indzhir M. Boldyreva, Delyash N. Muzraeva \\ Kalmyk Scientific Center of the Russian Academy of Sciences, \\ Russian Federation
}

The article analyzes folklore materials associated with the dog in the Kalmyk and Tuvan oral traditions. A comparative study of certain cultural elements of the closely related peoples allows, with due regard of common basic elements of community, to complete the general system of representations and concepts that constitute ethnic culture.

Due to the special role of the dog in the economy and culture of Kalmyks and Tuvans, the didactic narrative and pragmatics evidently prevail in the bulk of plots and motifs both in the Mongolian (Kalmyks) and Turkic (Tuvans) traditions, despite the observed commonness of other plots and motifs. The paper reveals certain correlations between images of the dog and the wolf. There are multiple stories describing a couple of dogs. 'Four-eyed' dogs (with spots above the eyes) are considered sacred. Dogs play a special role in national wedding rites.

The research materials include audio recordings of the 1960-1980s stored in the Scientific Archive of the Kalmyk Scientific Center of the Russian Academy of Sciences, as well as published samples of Tuvan fairy tales and epic genres.

Keywords: dog; totemic animal; folklore; rites; wedding rites; signs; healing ability; Kalmyks; Tuvans

"The reported study was funded by government subsidy - project name 'Oral and Written Heritage of the Mongolic Peoples of Russia,

Mongolia and China: Cross-Border Traditions and Interactions' (registration number AAAA-A19-119011490036-1).

\section{For citation:}

Burykin A. A., Boldyreva I. M. and Muzraeva D. N. The dog in Kalmyk and Tuvan folklore. The New Research of Tuva. 2019, № 4. URL: https://nit.tuva.asia/nit/article/view/888 (access date ...). DOI: 10.25178/nit.2019.4.10

\section{Введение}

Калмыки и тувинцы - народы, имеющие общие черты в культуре, приобретенные за многие века существования в Центральной Азии в относительно постоянном этническом окружении тех же монгольских и тюркских народов, к которым они принадлежат. Культура и повседневная жизнь народов обладают способностью отражаться в устном искусстве - в фольклоре. Далеко не все аспекты этнографии калмыков и тувинцев изучены в равной мере. Домашние животные - предмет исследования в хозяйстве народа, но не менее интересно рассмотреть компоненты мира животных в духовной культуре народа, в частности в фольклоре. Собака, как показывает анализ литературы, в этнографических исследованиях по калмыкам и тувинцам представлена недостаточно, хотя нам удается обнаружить интересные фольклорные материалы и культурные представления, связанные с собакой и указывающие на некоторые общие элементы в фольклоре этих народов.

Цель настоящей статьи - проанализировать фольклорные материалы, имеющие отношение к собаке, в калмыцкой и тувинской устной традиции, тем самым попытаться проследить два уровня отношения к собаке в традиционной культуре - то, что существует в реальности этнографической культуры и поддается непосредственному наблюдению в этнографических исследованиях и то, что обобщается на более высоком уровне - в фольклоре, часто с дидактической направленностью.

Источниковой базой исследования являются аудиозаписи образцов калмыцкого фольклора, собранные учеными-фольклористами Калмыкии в 1960-1980-х гг. и публикации по тувинскому фольклору 1970-х-2000-х гг. В настоящее время эти аудиозаписи хранятся в Научном архиве Калмыцкого научного центра РАН (НА КалмНЦ РАН. Ф. 16. Опись 1, Опись 2), а также издания текстов калмыцкого фольклора (Медноволосая ..., , 1964; Сандаловый ларец, 2002) и наиболее представительные издания образцов тувинского фольклора (Таубе, 1994; Тувинские героические сказания, 1997; Тувинские народные сказки, 1971; Тувинские народные сказки 1994). Они включают уникальные произведения разных жанров устного народного творчества. Среди них образцы волшебных, бытовых сказок, сказок о 
животных, легенд, преданий, имеются и образцы малых жанров калмыцкого фольклора, посвященные собаке, в основном это наставления-предписания. Эти материалы в целом и в деталях, связанные с отдельными компонентами культуры, недостаточно освоены как фольклористами (в них нет обобщений по системе персонажей), так и этнографами.

Собака - одно из домашних животных, наиболее близких к человеку. От собаки часто зависит благополучие людей; собака является помощником человека на охоте, в охране стад и жилища. В силу близости собаки к социуму людей формируется и особое отношение к ней, складывается множество иррациональных представлений, связанных с ней, а также создается ее особая роль в картине мира. В Энциклопедии «Мифы народов мира» в статье «Животные» собаке уделено незаслуженно мало места (Мифы народов мира, 1991: 440-449), а статья, посвященная собаке, отсутствует вообще. Тем не менее, этнографами собран весьма объемный материал о роли собаки в представлениях и верованиях народов Центральной и Восточной Азии, создающий основания для сопоставительного анализа и дающий точку отсчета для дальнейших разысканий (см., например: Самар, 2010: 89-143).

Наше исследование показывает, что, очевидно, из-за особого очень важного значения собаки в хозяйстве и культуре калмыков и тувинцев дидактический нарратив и прагматика явственно преобладает над общностью сюжетов и мотивов в монгольской традиции (калмыки) и тюркской традиции (тувинцы), несмотря на наблюдаемую общность иных сюжетов и мотивов (см. в особенности: Таубе, 1994). Сравнительное исследование элементов культуры ареально близких народов позволяет при наличии общих базовых элементов общности (в данном случае для нас достаточно скотоводческого хозяйства и кочевого образа жизни) достраивать общую систему представлений и понятий, формирующих этническую культуру.

На протяжении многих столетий происхождение собаки народы Центральной Азии связывали с высшими силами, обожествляли само животное. Ежегодно во время праздника Зул калмыки готовят лодочки из теста, в которые помещают столько фитилей, сколько человек в семье. Интересен обычай зажигания лампад у народов, проживающих в монгольском Алтае (алтайских урянхайцев, баитов, дербетов, торгутов, захчинов, мингатов, олётов, халхов), описанный известным монгольским этнологом М. Ганболдом, который имеет большое сходство с калмыцким обрядом продления возраста всеми людьми в народный праздник Зул: «Вечером 25 дня первого зимнего месяца зимы ойраты-монголы $<. .>$ после того как скот уже собран с пастбищ, по количеству членов семьи, рода скота и собак (если в семье пять человек, 4 рода скота и две собаки, тогда зажигают 11 лампад), готовят и зажигают лампады» (Трансграничная культура ..., 2016: 207). Продление возраста распространяется не только на людей, но и на всех домашних животных, в том числе и на собак. Собака - верный караульщик скота - основного достояния кочевника. Собака играет такую большую роль в жизни скотовода, что она представляется ему чуть ли не членом семьи и воплощением души близких родственников. Недаром убийство собаки у калмыков приравнивается к убийству человека (Душан, 2016: 211). У тувинцев собака жила у хозяев до смерти: «Убивать собаку строжайше воспрещалось. Когда собака умирает от старости, в рот вкладывают сало и хоронят. Но не бросают» (Серен, 2015: 154).

Надо отметить, что ни с одним другим домашним животным человек не проявляет столь большой близости, как с собаками. Вероятно, это связано с тем, что собака реально охранаяет жизнь хозяина в природе и защищает его от опасностей, а также со сложным поведением собаки возле человека. Похоже, и калмыки, и тувинцы-собаководы заметили, что собака очень чувствительна не только к окружающему миру, где она первой воспринимает опасность, но и к эмоциональному состоянию хозяина, его заботам и тревогам, радости и печали.

\section{Волк и собака в религиозно-мифологических представлениях калмыков и тувинцев}

Анализ этнографической литературы показывает важную роль собаки и волка в религиозно-мифологических представлениях монгольских и тюркоязычных народов, в частности калмыков и тувинцев.

Э. П. Бакаева пишет: «В добуддийских верованиях калмыков, связанных с почитанием животных, прослеживались пережитки ранних форм верований. Тотемические представления сформировались в сфере этнических предков калмыков - ойратских племен, из различных этнических групп которых в дальнейшем образовался новый этнос. Реликты тотемических представлений особенно ярко отражены в этнониме чонс («волки»), кличе (уране) этих этнических групп и вере в родство ее представителей с прародителем, вскормленным волчицей» (Бакаева, 2010: 454). 
Волк и собака в сознании людей были тесно связаны, хотя эта связь и не отмечена в вышеназванной энциклопедии в статье о волке (Мифы народов мира, 1991: 242-243). Тотемно-культовое значение волка продолжалось в культе собаки. В известном эпизоде из «Сокровенного сказания монголов» говорится о сакральной значимости собаки: прародительница Чингис-хана - Алан-Гоа, родившая пятерых сыновей, трех из них - после смерти мужа, объясняя их рождение, говорит сыновьям, что «каждую ночь, бывало, через дымник юрты, в час, когда светило внутри (погасло), входит ко мне светло-русый человек; он поглаживает мне чрево и свет его проникает мне в чрево. А уходит так: в час, когда солнце с луной сходится, процарапываясь, уходит, словно желтый пес. Что ж вы болтаете всякий вздор? Ведь если уразуметь все это, то и выйдет, что эти сыновья отмечены печатью небесного происхождения» (Козин, 1941: 6). Нам удалось найти у тувинцев интересный этиологический сюжет, связанный с происхождением волка от собаки при присутствии и пассивном участии в нем человека: «Мальчик здоровым и невредимым вернулся к своей стоянке. Его раненая собака погибла в степи и при следующем воплощении явилась на свет волком. Говорят, что так и произошло существо, которое называют волком» (Таубе, 1994: 210). Можно думать, что собака превратилась в волка, будучи покинутой своим хозяином, и тем самым изменила свое отношение к человеку и его хозяйству на противоположное. Есть основания полагать, что русское слово собака происходит от местоименного корня себ соб с именным суффиксом -ак-, и показателем женского рода $a$, и его исходное значение «одинокая волчица, пришедшая к людям».

Как и в культуре других народов, волк и собака связываются с генеалогией персонажей и отдельных общностей, эти представления связываются с тюркютами, но здесь известные материалы неоднородны и не внушают доверия. Эти сюжеты составляют отдельную проблему, которая требует новых исследований в общем плане сюжетов об этнической генеалогии тюркских и монгольских народов.

У калмыков издавна проявляется особенное отношение к животным. Издревле собака была близким другом кочевников, их помощником, защитником и другом. Об этом повествуется в «Эвдин нойна туск туужд» ('Сказании об Эвдин нойоне’), записанном М. Э. Джимгировым, Н. Н. Убушаевым, Б. Б. Оконовым, В. Д. Пюрвеевеем от информанта Н. К. Тюрбеева (Юстинский р-н, с-3 «Сарпа»)1.

Во время бегства с Алтая тридцати трех всадников, к одному из них, которого звали Ширвяд, прибилась гавш шар ноха - 'желтая моська'.

Когда они поднимались вверх по течению реки Яик, им навстречу вышел один из двух огромных волков, размером с двухлетнего жеребенка, с трехгодовалую корову, извергающий из пасти пламя. Ханское войско в страхе пустилось в бегство, но собачка, спрыгнув с крупа коня, с лаем бросилась навстречу волку. Хан повернул войско назад и все с криком стали натравливать собаку на волка. Вцепившись друг другу в глотки, они погибают в смертельной схватке (там же).

Мотив привязанности собаки к роду людскому присутствует в предании «Көгшн нохан тускар (тууж)» ('Предание о старой собаке'), записанном М. Э. Джимгировым и А. И. Сусеевым у сказителя Я. И. Борлыкова, родившегося в 1881 г. в Бага-Дербетовском нутуке, хотоне Годжур (время записи - 1965-1966 гг.) ${ }^{2}$.

Собака всегда была недремлющим стражем. В ойратском сказании «Дөрвн өөрд дөчн түмн моңһлла дәәлдж һарч ирснә туск туужд» ('Сказание о разгроме сорокатысячного войска монголов дербен-ойратами') один из монгольских воинов, вернувшись из разведки, сообщил своим соплеменникам, что собаки дербен-ойратов настолько злы, что в их в лае слышится: «Ид, бәр, ал!» - 'Ешь, лови, убей!' (информант М. Дорджиев, Астраханская обл., год записи - 1971) ${ }^{3}$.

В 'Сказании об Эвдин нойоне' также упоминается о синих волках, называемых чондһн (возможно, 'помесь волка и собаки', 'волчья собака'), на которых охотился хан (там же).

В статье «Б. Х. Тодаеван дунсян «Ноха мис хойр» домгин тускар» ('Дунсянская ${ }^{4}$ легенда о собаке и кошке', записанная Б. Х. Тодаевой»), автором Осорин Утнасун проведен сравнительный анализ вариантов «Легенды о кошке и собаке», бытовавших во Внутренней Монголии, Южной Монголии и в Калмы-

\footnotetext{
${ }^{1}$ Эвдин нойна туск тууж ['Сказание об Эвдин нойоне']. Информант Тюрбеев Н. К., Юстинский р-н, с-з Сарпа. Зап. в 1967 г. М. Э. Джимгировым, Н. Н. Убушаевым, Б. Б. Оконовым, В. Д. Пюрвеевеем. - НА КалмНЦ РАН. Ф. 16. Оп. 1. Кас. № 63 (72) 8.

${ }^{2}$ Көгшн нохан тускар (тууж) ['О старой собаке (предание)']. Информант Борлыков Я. И., Малодербетовский район. Зап. в 1965-1966 гг. М. Э. Джимгировым, А. И. Сусеевым. - НА КалмНЦ РАН. Ф. 16. Оп. 2. Кас. № 234 (5), (243).

${ }^{3}$ Дөрвн өөрд дөчн түмн моңһлла дәәлдж һарч ирснә туск тууль ['Сказание о разгроме сорокатысячного войска монголов дербен-ойратами']. Информант Дорджиев М. Б. Зап. Н. Ц. Биткеевым, Э. Б. Оваловым, Н. Б. Сангаджиевой в 1971 г., Астраханская обл., Лиманский р-н, с. Лесное (Көрә). - НА КалмНЦ РАН. Ф. 16. Оп. 1. Кас. № 114 (123), (3).

${ }^{4}$ Дунсянский язык (широнгол-монгольский, санта, саньта) - язык народа дунсян, один из монгольских языков.
} 
кии. В дунсянских легендах собака и кошка возвращают хозяину украденное кольцо, становятся спасителями рода людского, сохранив им средство для пропитания. В калмыцкой версии данной легенды мальчик покупает животных у старика, пытавшегося избавиться от них, и тем самым спасает им жизнь, которые отплачивают ему добром (Утнасун, 2015: 201).

В сказке «Өнчн көвүн» ('Мальчик сирота’), записанной А.Ш. Кичиковым, А. В. Бадмаевым и 3. Б. Улюмджиевой от информанта А. Утнасунова (с. Чилгир Яшкульского р-на, год записи - 1968) буддийский монах, превратившись в кошку, помог бедному слуге жениться на дочери Водяного хана 1 .

В этих легендах и сказке присутствует кошка, которая у калмыков считается собакой бога и гелюнгом² животных (Душан, 2016: 212). Тема кошки для таких сюжетов заслуживает отдельного исследования.

В сказке «Хан богд аавта, хатн сәәхн ээжтә Хәәртә Хар Күкл» ('Хяярта Хар Кюкюл с благородным царем-отцом и прекрасной царицей-матерью'), записанной Е. Г. Бембеевой, говорится об ик теңзрин hалзн һал ноха ('огромной небесной огненной лысой собаке'), повесившей на один клык богатство сотен человек, на другой - богатство сотен человек' (информант Б. М. Найминова, Приозерный р-он, год записи -1977$)^{3}$. В данной сказке небесная собака предстает грозным хищником.

В калмыцкой сказке «Старик с гончей собакой», опубликованной Г. Рамстедтом (Каlmückische Sprachproben, 1909: 13-18), собака выступает мистическим защитником, имеющим семьдесят две способности. Лучшие ханские борзые не смогли догнать лису-шулму. Лишь гончая старика догнала и была уже готова схватить ее, но от резкого крика хана она вздрогнула, опрокинулась и испустила дух. Погибла и лиса. Старик заплакал: «Я ведь просил вас не кричать. Лиса-шулма проявила семьдесят одну хитрость, собака моя - тоже семьдесят одну. Она погибла, потому что вы помешали ей проявить семьдесят вторую хитрость». Текст этой сказки, записанный Л. С. Сангаевым в 1961 г. в пос. Яшкуль Калмыцкой АССР у пятидесятилетнего сказителя Тюмида Кичикова, позднее был включен в сказочный сборник (Медноволосая ..., 1964: 249-251).

В калмыцких сказках «Жижларам шулм күүкн» (‘Девушка-ведьма Джиджларам’) в записи М. Э. Джимгирова и Е. Д. Мучкиновой (информант Санджиева Ц., с. Хар-Булг Черноземельского р-на, год записи - 1969)4, «Нарн Арслң хан Сар Арслң дүүтә» ('Хан Наран Арсланг и его младший брат Сар Арсланг'), записанной Н. Ц. Биткеевым и Б. Б. Оконовым от информанта Н. С. Балеева (с-з Сухотинский Приозерного р-на, год записи - 1974), собак приносят в жертву, чтобы спасти детей хана от мачехи злой ведьмы ${ }^{5}$.

Преданность собаки человеку отмечается у калмыков даже в тех фольклорных повествованиях, где собака принадлежит врагу героя: в сказке «Три брата» герой убил собаку и беркута мангаса, защищавших своего хозяина (Медноволосая ..., 1964: 107). В варианте сказки «Три брата» собака спасает кобылицу (Калмыцкие народные сказки, 1978: 89).

Особое отношение к собаке у калмыков словесно выражено в следующем фрагменте сказки:

«А старший брат говорит:

- Сепяка, вон у тебя лежит, свернувшись, собака. Не продашь ли ее нам?

- Нет, не продам. Это у меня единственная собака. В степи она мне скотина. В руках она мне дитя» (Медноволосая ..., 1964: 211-212).

Этот фрагмент выразительно показывает особую ценность собаки для калмыков независимо от материального положения человека или семьи, и особое эмоционально обогащенное отношение к животному, особо близкому к человеку, тем более одинокому.

Анализ фольклорного материала калмыков и тувинцев показывает какая важная роль отводится собаке и волку в религиозно-мифологических представлениях монгольских и тюркских народов. В обеих

${ }^{1}$ Өнчн көвүн ['Мальчик сирота']. Информант Утнасунов А. Д., Яшкульский р-н, с. Чилгир. Зап. в 1968 г. А. Ш. Кичиковым, А. В. Бадмаевым, З. Б. Улюмджиевой. - НА КалмНЦ РАН. Ф. 16. Оп. 1. Кас. № 74 (65), (9-10).

${ }^{2}$ Гелюнг - буддийский монах.

${ }^{3}$ Хан богд аавта, хатн сәәхн ээжтә Хәәртә Хар Күкл [’Хяярта Хар Кюкюл с благородным царем-отцом и прекрасной царицейматерью’]. Информант Найминова Б. М., г. Элиста. Зап. в 1977 г. Е. Г. Бембеевой. - НА КалмНЦ РАН. Ф. 16. Оп. 1. Кас. № 160 (1),(169), № 161 (2), (170).

${ }^{4}$ Жижларам шулм күүкн ['Девушка-ведьма Джиджларам']. Информант Санджиева Ц., Черноземельский р-н, село Хар-Булг. Зап. в 1969 г. Е. Д. Мучкиновой, М. Э. Джимгировым. - НА КалмНЦ РАН. Ф. 16. Оп. 1. Кас. № 94 (103), (6).

${ }^{5}$ Нарн Арслң хан Сар Арслң дүүтә ['Хан Наран Арсланг и его младший брат Сар Арсланг']. Информант Балеев Н. С., Приозерный р-н, с-з Сухотинский. Зап. в 1974 г. Н. Ц. Биткеевым, Б. Б. Оконовым. - НА КалмНЦ РАН. Ф. 16. Оп. 1. Кас. № 153 (162). 
традициях выразительно покаывается ценность собаки, бережное отношение к ней, и важно то, что собака у калмыков и у тувинцев играет активную роль, участвуя в защите человека от посягательств на его жизнь. Цена жизни человека в этих рассказах для собаки явно выше, чем долг по охране жилища и имущества, которое в нарративах подается как бы по умолчанию.

\section{Парные образы собак в фольклоре калмыков и тувинцев}

В сказочном фольклоре калмыков и в героических сказаниях и фольклоре тувинцев не всегда собака является одиночным персонажем, нередки истории, в которых фигурирует пара собак, и такие сюжеты и мотивы оказываются общими для устных традиций двух народов. Так, в калмыцких сказках часто можно встретить собак Хасыр (Хаср) и Басыр (Баср) - помощников и защитников сказочного героя. Они спасают хозяина от семисаженного волка (Герлтсн сувсн ..., 2014: 38-41), охотятся на парнокопытных (Манджиева, 2016: 39-42). Собаки с именами Хасыр и Басыр - отдельная группа персонажей калмыцких фольклорных повествований. Они фигурируют, напимер, в сказке «Зальта-Мерген-Баатр и мудрый конь его Золь-Цоохор» (Медноволосая ..., 1964: 46). Собаки с такими именами верно служат своему хозяину богатырю Шарвада (Сандаловый ларец, 2002: 97-98). Эти собаки играют особую роль среди зооморфных персонажей мифологии, о чем свидетельствует следующее описание, дающее нам представление о связи фольклора и мифологии с изобразительной практикой калмыков, что присутствует в словесных описаниях произведений искусства: нечто подобное мы видим в некоторых версиях калмыцкого эпоса «Джангар», где ставка хана Джангара украшена изображениями, делающими ее похожей на буддийскую ступу: «На дверцах ставки была изображена гордо парящая в воздухе Гаруда, на косяках - собаки Басар и Хасар, на верхнем косяке - попугай. На решетке и жердях крыши были вырезаны бодающиеся козлы, на подпорках - львы и тигры» (Калмыцкие народные сказки, 1978: 39). Собаки с этими именами встречаются и в других повествованиях (Владимирцов, 2003: 466, 494). Происхождение и распространение этого сюжета пока не раскрыто, и здесь пока даже взаимные параллели в фольклоре калмыков и тувинцев имеют значение для освещения темы. Возможно, что сами изображения этих собак имели охранительные функции, замещая реальных сильных и злобных псов. Как отмечается в коментариях к текстам, Хасар и Басар - клички сторожевых и охотничьих собак (Калмыцкие народные сказки, 1978: 67 прим.), имена, даваемые хорошей собаке (Владимирцов, 2003: 534), традиционные клички собак в калмыцком фольклоре (Сандаловый ларец, 2002: 223).

Две собаки со сходными именами - Эгер и Казар - встречаются в тувинском фольклоре (Тувинские героические сказания, 1997: 77, 78, 536; Тувинские народные сказки, 1971: 109).

В сказке «Эргил-оол» присутствуют собаки Озер и Газар:

«Встав утром, наш Эргил-оол тотчас собрался и поехал прямо на север, вслед за своим добрым

знакомцем. И, скача по дороге, он вспомнил слова, сказанные ему накануне его добрым другом.

- Когда ты взберешься на большую и высокую гору Сюмбер, то увидишь тогда перед собой большое море, - сказал он. - Если ты, высоко подняв полы своего халата и, закрыв глаза, прыгнешь на середину этого моря, то там окажется дом, сложенный из трех домов, вставленных друг в друга, к нему привязаны собаки Озер и Гозар. Как будто не видали они никогда человека, набросятся на тебя собаки Озер и Гозар. А ты, подумав о том, что эти собаки еще никогда не видали человека, - хлоп! и опустишь полы своего халата, и обе собаки остановятся» (Таубе, 1994: 59).

В сказке «Хара Буурул Дюжюмел» присутствуют собаки Азар и Базар: ХХара Буурул Дюжюмел скакал себе да скакал. Он въехал на гору и огляделся вокруг. И увидел он белую юрту-дворец, достававшую до неба. Хоть перед дверью и лежали два пса, Азар и Базар, но, когда Хара Буурул Дюжюмел вихрем пронесся с горы мимо юрты-дворца, собаки Азар и Базар не смогли схватить его» (Таубе, 1994: 132).

В сказке «Мальчик с тысячью буланых лошадей» эти собаки выступают как помощники героя: «Я вот-вот попаду в руки старой мангысихи. Пусть узнают об этом мои собаки Гезер и Базар» (там же: 206). Похоже, что эти образы заимствованы из фольклора монгольских народов, тем более, что у тувинцев имена этих собак неусточивы и изменчивы от текста к тексту, но отражают общую для калмыков и тувинцев традицию положительного отношения к собаке.

У обоих народов собаки с похожими именами верно служат своим хозяевам, охраняя их жилища, у калмыков собаки с такими именами задействуются в охоте, у тувинцев они только охраняют жилища. Тем не менее, как показывает текст сказки «Хара Буурул Дюжюмел» в нем проявляется представление о том, что человек имеет власть над любой, даже самой мощной и свирепой собакой, и способен смирить ее. 
Общность киноморфных персонажей в фольклоре калмыков и тувинцев должна свидетельствовать о заметном влиянии монгольского фольклора на фольклор тувинцев и стимулировать дальнейшие исследования в этой области. Обоснованием монгольского происхождения этих персонажей свидетельствует то, что они фигурируют в мифе «Млечный путь и Большая Медведица», в котором повествуется о двух собаках с именами Хасар и Басар:

«Давным-давно это было - во времена переселения народов. Сотни тысяч людей с несметными стадами скота отправились на запад. С тех пор даже на небе видна эта дорога, Млечный путь называется. Вел народы Хухэдэй Мэргэн, меткий стрелок. По звездам видно, как он гнался за тремя маралухамиоленихами. Среднюю прострелил насквозь стрелой. Три олененка бегут следом за матерями-оленихами. За ними гонится Хухэдэй Мэргэн, а с ним рядом бегут две собаки Хасар и Басар. Именно так и звезды расположены на небе» (Скородумова, 2003: 27). Собака по имени Хасар встречается в монгольском «Сказании об Буджин-Дава-хане».

Судя по всему, собака по имени Хасар или две собаки с похожими именами первоначально появились в монгольской мифологии; присутствие этих персонажей у тюрок, как пока можно судить, ограничено фольклорными текстами тувинцев, в основном тувинцев Монголии.

\section{“Четырехглазые” собаки и их сверхъестественные способности}

А. Г. Митиров, на основе собранных фольклорных материалов и исторических сведений, рассматривал образ собаки в верованиях многих народов, в том числе и тюрко-монгольских. Он отметил, что собака не только охраняет жилище и имущество человека, она является стражем трех миров как «небесная собака, или волк - существо верхнего мира; как спутник кочевника - существо срединного мира; в качестве четырехглазой собаки как проводник душ в мир мертвых» и в народном веровании она играет большую роль (Митиров, 1977: 46). У. Д. Душаном подробно описаны хорошие и плохие предзнаменования, связанные с собакой (Душан, 2016: 212).

Четырехглазых собак - собак с пятнами над глазами - калмыки называют священными собаками (зуугийн нохой). Согласно калмыцкой легенде, первая из них пришла в Монголию вместе с паломниками, ходившими в Тибет поклониться буддийскому божеству. Считалось, что эти священные собаки высматривают своей дополнительной парой глаз злых духов, а также они способны подолгу сидеть неподвижно, медитируя и творя молитвы за своих хозяев. Когда священная собака умирает, ее хоронят головой на юг, чтобы ее душа вернулась в Тибет и переродилась в человека ${ }^{1}$.

Особое отношение к таким собакам и признание за ними особых способностей отмечено также у тувинцев. П. С. Серен отмечает, что «в традиционной культуре тувинцев особое место занимает четырехглазая собака, т. е. такая, которая над глазами имеет пятна. Она, увидев смерть, начинает лаять и выть, поэтому, когда воет собака, значит где-то ходит смерть. Это примета смерти хозяина собаки» (Серен, 2015: 154). У тувинцев сомонов Цагаан-Нуур считается, что четырехглазая собака не допускает в жилище нечистую силу, чертей <...> (там же: 154).

О черной собаке с белыми дугами над бровями и связанными с ней представлениями у тувинцев писал Л. П. Потапов: «В последний день каждого лунного месяца, в будуун, на небе нет видимой луны, нет ее и в первый день нового лунного месяца - в эти дни, по поверью, луну может видеть только черная собака с белыми дугами над бровями и белым пятном на груди» (Потапов, 1969: 291). Такое же отношение к собакам с пятнами над глазами мы наблюдаем у нанайцев (Самар, 2010: 94), а также у эвенков и эвенов (Бурыкин, 2001: 91), что указывает на южные источники подобных представлений, которые оказываются следствием ранних тунгусо-монгольских или тунгусо-тюркских контактов, датируемых временем проникновения буддизма к народам Центральной Азии.

\section{Собака в свадебной обрядности у калмыков и тувинцев}

Свадебная обрядность имеет важное значение в системе обрядов жизненного цикла монгольских и тюркских народов. Знакомство с описаниями свадебных ритуалов, системой представлений и гаданий о замужестве и проч. показывает, что в калмыцких и тувинских свадебных ритуалах прослеживается особая роль собаки, а это, в свою очередь, наделяет собаку дополнительными характеристиками в ее

${ }^{1}$ Собаки и церковь: отношение к собакам в мировых религиях [Электронный ресурс] // Заметки о собаках. URL: http://okdzks. com/page.php?id=193 (дата обращения: 09.10.2019). 
связях с людьми: собаке отводится роль посредника между членами семьи и невестой, входящей в семью ее хозяев из другого сообщества - рода или территориальной группы.

Калмыки привезенную невесту заставляли кланяться очагу, солнцу и всем родственникам, при этом она должна была бросать кусочки жира в огонь, в отца жениха и родственников. Остатки кусков жира выносили и бросали собаке (Душан, 2016: 140). Такую же важную роль собака играла в обрядности тувинцев - с ее помощью гадали, кто из собравшихся девушек первой выдет замуж (Серен, 2015: 154).

Согласно свадебному обряду («Күүкн хәрд һардгин тускар» - 'О замужестве девушки’), записанному Б. Б. Оконовым у сказителя П. А. Санциева (Багацохуровский улус, с-з Барун), год записи - $1980^{1}$, после благопожеланий в адрес молодых, в правый подол свадебного платья невесты, - каким бы дорогим оно ни было, - клали кусочек мяса и, подозвав собаку, угощали. Калмыки считали, что счастье дома, семьи - в невестке и собаке. Невестка, войдя в новую семью, становилась хранительницей рода. Собака, обернув себя паутиной дома, охраняла счастье хозяина (там же).

Очень интересный обычай установления связи новобрачной с собакой жениха у тувинцев описан Л. П. Потаповым: «После расплетения девичьей косы и заплетения волос на три косы невеста садилась у двери юрты и, положив под правую полу своей свадебной одежды кусок овечьего жирного мяса и кусок сала, скармливала их собаке, принадлежащей жениху. Это делалось для того, чтобы ее будущий муж и его родственники жили хорошо и в полном достатке. Во время кормления собаки присутствующие в юрте произносили всевозможные хорошие пожелания (желали невесте счастья и благополучия в супружеской жизни)» (Потапов, 1969: 260).

На калмыцкой свадьбе непременно произносили йорелы-благопожелания. Один из таких образцов приведем в записи Е. Э. Хабуновой: В нем присутствует собака:

Күүнд му келүллго, 'Пусть никто [плохого] слова [вам] не говорит,

Нохад хуцуллго, Собака [на вас] не лает’ (Информант М. Лиджиева, Малодербетовский р-он; год записи -1984$)^{2}$.

В пожеланиях, адресованных молодым, ярко выражены соблюдение норм этикета. Наряду с человеком, здесь упоминается и собака, так как калмыки считали, что собаки интуитивно чувствуют недобрых людей.

Для традиционного свадебного обряда тувинцев характерным было произнесение благопожеланий (йөрээлов) с пожеланием благополучия, счастья и богатства (Юша, 2008: 53). Помимо этого, как отмечает Ж. М. Юша, «Имеются благопожелания невесте, в которых содержатся наставления-запреты. Например, к невесте обращались с таким благопожеланием-наставлением:

Хараганныг хову кежир кылаштава,

Кокай кончуг эвеспе уруум.

Ажынгаштың арт ажыр кылаштава,

Адыг кончуг эвеспе, уруум.

'Не переходи степь, покрытую

караганниками,

Волк опасен, дочь моя.

Рассердившись, не переходи за перевал,

Медведь опасен, дочь моя’» (там же: 55).

В этом наставлении невесты звучит назидание с предостережением в котором упоминается волк здесь оно облечено в конкретную форму образа местности, но, очевидно, благопожелание имеет большую степень обобщения именно в отношении животного, хотя отношение женщин к волку требует дополнительного исследования как в культуре тюркских, так и в культуре монгольских народов.

Традиционно во время свадебного торжества у калмыков произносился «Яс кемәлһн» ('Сказывание по кости') - уникальный жанр калмыцкого устного народного творчества, представляющий собой

1 Күүкн хәрд һардгин тускар [‘О замужестве девушки’]. Информант Санциев П. А., Октябрьский р-н, с-з Барун. Зап. в 1980 г.

Б. Б. Оконовым. - НА КалмНЦ РАН. Ф. 16. Оп. 2. Кас. № 236 (227).

Йөрәл ['Благопожелание']. Информант Лиджиева М., Малодербетовский р-н. Зап. в 1984 г. Е. Э. Хабуновой. - НА КалмНЦ РАН Ф. 16. ОП. 2. К. № 307 (298). 
магталы-восхваления, в исполнении которых участвовали два сказителя (Горяева, Болдырева, 2017: 79-87). «Сам по себе двадцать пятый позвонок бараньего хребта является символом мирового древа» и рассказывание «Яс кемялген» во время свадебного пира имело магический оттенок и было связано с символикой новой нарождавшейся жизни (Басангова, 2007: 249-251).

В числе первых, в чей адрес произносилось восхваление, была собака. Второй же участник, выслушав, высказывал восхищение: «Мууха сәәхн < ..> күчр бүдүн нохав!» ('Какая замечательная < ..> довольно большая собака!’) (информант М. Б. Дорджиев, Астраханская обл., записано в 1970 г. Н. Ц. Биткеевым) 1 , «Пөө-nө, күчтә хурдн ноха бәәжл терчн» ('О-о, довольно быстрой собакой была она’) (информант Т. Лиджиев, с-з Сарпа Юстинского р-на, записано в 1980 г. Н. Ц. Биткеевым)². Таким образом, у калмыков в свадебной обрядности проявляется роль собаки как существа, способствующего социализации невесты в новой семье.

Знакомство со свадебной обрядностью двух народов указывает на то, что в традициях обоих описываемых народов собака выполняет роль того, кто приобщает невесту к роду и семье мужа, устанавливает ее связи с ее новой семьей. В какой мере в этих обрядах задействуются сверхъестественные представления об охранительной функции собаки, и в какой мере в них проявляется вполне прагматичный опыт социализации нового человека среди хозяев собаки с целью дать собаке признать новую хозяйку и избежать конфликтов собаки с новым человеком, разобраться трудно, но, видимо, обрядовая практика учитывает как повседневную жизнь, так и традиционные религиозные представления.

\section{Собака в фольклоре и традициионной культуре тувинцев и калмыков по данным анализа фольклорных текстов}

Мы уже могли наблюдать некоторые общие черты отношения к собаке и ее функции в культурно значимых действиях калмыков и тувинцев, зафиксированные в устных традициях этих народов (см. выше).

У тувинцев, как и у калмыков, собака выступает как помощник и защитник богатыря: ср. сказку «Богатырь Тевене-Меге и конь его Демир-Шилги (Тувинские народные сказки, 1971: 23-24). Собака становится атрибутом взрослого состояния героя: в сказке «Дээр-Меге и шестиголовый мангыс Калчаа-Мерген», мальчик, становясь охотником, просит подарить ему двух охотничьих собак (там же: 112). В сказке «Оскюс-оол и красавица, излучающая свет солнца и луны» герой просит у хана рыжую собаку, которая оборачивается красавицей (там же: 123-124). Так реализуется мотив добывания героем своей избранницы, а оборотничество собаки становится ее значимым свойством в представлениях о сверхъестественном.

В некоторых сказках ойратов собака превращается в девушку-красавицу (Владимирцов, 2003: 305), аналогичные мотивы есть у тувинцев, как отмечается в комментариях, он имеет тибетские параллели (Таубе, 1994: 332).

В тувинской сказке «Старик Эндз Дендз, или Юноша с собакой, кошкой и рыбой» юноша покупает кошку и собаку, и они становятся его помощниками (там же: 210-211).

Интересно проследить, какое отражение получила собака, равно как и волк, в пословицах и поговорках тувинцев и калмыков. Несмотря на то, что у тувинцев заведомо преобладает упоминание домашних животных, от которых зависело благополучие и достаток семьи, в них хоть и редко, но упоминается собака. Приведем пример: «Ыт - коданынга ынак» ('Даже собака привязана к своему двору’), что говорит о присутствии собаки в жизни человека, о связи между ней и ее хозяином. О том, насколько значима ее роль для номада, говорит другая пословица: «Аът - кижинин буду, ьы - кулаа» (‘Лошадь нога человека, собака - уши').

Тесная связь собаки и человека прослеживается в калмыцкой пословице «Ноха - эзндән, шовун үүртән» (“Собака - хозяину, птица - гнезду’). Собака с малого возраста привыкает к хозяину, который кормит, обучает ее, и потому ради него она готова пожертвовать своей жизнью. Тогда как у птиц нет никого кроме цыплят (Хальмг үлгүрмүдин ..., 2011: 130).

${ }^{1}$ Яс кемәлһн ['Сказывание по кости']. Информант Дорджиев М. Б. Зап. в 1970 г. Н. Ц. Биткеевым. - НА КалмНЦ РАН. Ф. 16. Оп. 2. Kac. № 244 (235), № 35 (10).

Яс кемәлһн ['Сказывание по кости']. Информант Лиджиев Т., Юстинский р-он, с-3 Сарпа. Зап. в 1980 г. Н. Ц. Биткеевым. - НА КалмНЦ РАН. Ф. 16. Оп. 1. Кас. № 107 (98). 
По нормам этикета тувинцев, приближающийся к юрте человек должен был попросить хозяина отозвать собак, охраняющих юрту: «К дому подходят - Девушка вышла. “Есть ли собака? Отгони собаку, сестрица”, - сказав. Подошли» (Тувинские героические сказания, 1997: 437). В сказке «Чангаа-кузнец» говорится: «Кузнец начатую работу оставил, туда [ему] навстречу вышел, поздоровался, [помог] с коня сойти, свою собаку прогнал, дверь открыл, в юрту пригласил его войти (Мифы, легенды, предания тувинцев, 2010: 195). Точно такая же бытовая норма описана Л. П. Потаповым (Потапов, 1969: 160).

Отсутствие собаки, по представлениям тувинцев - свидетельство крайней бедности героя повествования: «И жил старик Багайтык. Его дочь Чечен-кыс была самой прекрасной во всем племени. И не было у них не то что скота - даже собаки у двери юрты» (Тувинские народные сказки, 1971: 171). Тут можно вспомнить особо трогательные чувства к единственной собаке, которые испытывает одинокий бедный герой калмыцкой сказки (см. выше).

Даже лай собак служит у тувинцев маркером социального положения их хозяев: «Тогда начал Орлан:

- О, богатые люди - это необыкновенные люди! У них все по-своему, все особенное, и в каждой мелочи видно их богатство. У них даже собаки лают полновесно, не так, как у простых людей.

Нойон не вытерпел, грудь его поднялась от гордости.

- Как, скажи, как лает моя собака, Орлан?

- О, голос у нее громкий, она лает басом: “Хонн! Хонн!” А собаки простых людей лают тонким голоском: “Хан-хан!"

Нойон радостно заулыбался.

- Значит, говоришь, моя собака лает: “Хонн! Хонн!” А собаки простых людей: “Хан-хан!”. Байская собака, значит; “Хонн! Хонн!” А собаки бедняков: “Хан-хан!” (Тувинские народные сказки, 1971: 175).

Сходный мотив есть в бурятских сказках (Бурятские народные сказки ..., 2008: 116).

Сытое состояние собаки у тувинцев выступает дополнительной характеристикой изобилия угощений на пиру. Это нашло отражение в пословицах и поговорках тувинцев, например, «Ыт думчуу борбаннатпа, уруг караа кыланнатпа» ('Собачонку накорми, ребенка - угости').

В сказке «Хараат Хаан и Джечен Хаан» говорится: «Хан отдал девушку в жены своему сыну, и уж тут был устроен большой пир: даже собаке было не поднять хвоста, а сироте не поднять живота - такой был задан пир» (Таубе, 1994: 256).

В повседневной культуре монгольские и тюркские народы нередко обращались к собаке, делая ее участником ритуалов. П. С. Серен пишет: «С ростом и воспитанием ребенка связан и такой обычай, когда у ребенка выпадал молочный зуб, то его обычно завертывали в кусок овечъего курдюка и давали собаке, приговаривая при этом “Мээё багай дижим алгаш, эки диштен бер” (букв. 'Бери мой плохой зуб, дай свой, хороший зуб'), а тувинцы сомона Цагаан-Нуур говорят “Мээё багай дижим алгаш, коя диштен бээр сен” (букв. ‘Бери мой плохой зуб, дай свой, красивый зуб’)» (Серен, 2015: 154). Данный обряд существует и у других народов. Например, калмыки молочный зуб завертывали в тесто или во что-нибудь съедобное. Монголы завертывали в кусок овечьего курдюка и давали собаке, приговаривая при этом «Бери мой плохой зуб, дай свой, молодой зуб» (там же). О таком обычае тувинцев писал и Л. П. Потапов (Потапов, 1969: 345).

Собака обладает целительскими способностями. В старину калмыки слюной собаки лечили раны, ссадины, язвы, а также избавлялись от гидраденита, или, как в народе его называют, собачьего вымени. Положив на пораженное место сладкое, они подзывали собаку. После того как собака вылизывала место, где находились сладости, считалось, что болезнь отступала. Собачий жир использовали при простуде, артрите. Собаку, которая укусила человека, не убивали до тех пор, пока не заживала рана. В таких случаях рану лечили пеплом сожженной шерсти укусившей собаки․․ Человек, побывавший на войне, где приходилось убивать врагов, мог с помощью собаки исцелить человека, надрезав собаке ухо и смазав ее кровью больное место (Болдырева, 2014: 91-95).

К плохим человеческим качествам у калмыков относилось хвастовство, о чем говорится в пословице, записанной Е. Г. Бембеевой: «Гергән буульсн күн - адг эргү, нохаһан буульсн күн эргү, бийән буулснь ах эргұ» (букв. 'Тот, кто хвалит жену, - глупец'; 'тот, кто хвалит собаку, - малый глупец', 'тот, кто хвалит

${ }^{1}$ Устное сообщение информанта - И. Ш. Манджиевой, 1949 г. р., дербетки (с. Троицкое Целинного р-на РК). 
себя, - большой глупец') (информант Б. М. Найминова, г. Элиста, год записи - 1977) ${ }^{1}$. В данной пословице собака входит в число родных и близких, которых, в целях защиты от дурного глаза, не принято было хвалить.

Наблюдая за поведением собаки, калмыки отмечали хорошие и плохие предзнаменования. Дурным предзнаменованием считалось, когда собака выла или же оставляла своего хозяина и уходила к другому. При этом ее бывший хозяин не стремился даже взять ее обратно. Полагают, что она, перестав признавать своего хозяина, тем самым предвещает смерть бывшему своему хозяину. Когда собака лежит в кибитке, повернувшись спиной к очагу, это считается знаком предвещающим несчастье. Ее заставляют вскочить сильными побоями, говоря: «Потеряй свою спину». Хорошим предзнаменованием считалось, если впереди человека испражнится собака. Полагают, что в этом случае непременно должно исполниться задуманное данным человеком. Идущий человек подходит к калу и прикасается ногой, говоря: «Пусть будет большой доход» (Душан, 2016: 212).

У тувинцев и у калмыков считалось дурным предзнаменованием, если собака вскакивала на крышу юрты. У тувинцев такую собаку полагалось убить (Потапов, 1969: 162; Душан, 2015: 211-212).

Калмыки считали, что у животных тоже есть свои небесные покровители. Существовали запреты, касающиеся собак: нельзя было их бить, иначе, считалось, не будет изобилия. В каждом доме обязательно должны быть собака и кошка. Собаки могли не только предупредить хозяев о грозящей им опасности, но и даже «забрать» то плохое, что ожидало семью. Когда умирали эти животные, хозяева, перед тем как предать земле, заливали им в рот масло (Boldyreva, 2015). Формирование особых ритуалов, связанных с собакой и их сложность, насыщенность культурными смыслами, свидетельствуют о большом значении собаки в традиционной культуре народов Центральной Азии.

Сведения, содержащиеся в приведенных примерах из фольклорных текстов, кратких описаний повседневной обрядности калмыков и тувинцев наглядно показывает общность базовых представлений о собаке как близком к человеку существе. Сходство прослеживается в наделении собаки сверхъестественными сенсорными способностями, приближении собаки к людям в свадебных обрядах, связанных с социализацией невесты в новой семье, сохранении полноты жизненного цикла собаки и в определенных ритуалах, обставляющих ее уход от людей, уход из жизни. Отличие в отношении к собаке у калмыков и тувинцев видится в том, что в сюжетах о паре собак у калмыков такие собаки занимаются охотой, в то время как у тувинцев они охраняют жилище человека, имеющего высокий общественный статус. Еще одно отличие, связанное с присутствием собаки в жилище калмыков и тувинцев заметно в том, что у калмыкови, по крайней мере по фольклорным данным, отражающим некую архаическую реальность, в хозяйстве непрепенно присутствует кошка, также маркированная особым отношением и особыми сверхъестественными представлениями.

\section{Заключение}

Таким образом, в традиционной культуре калмыков и тувинцев собака выступала в роли ближайшего друга кочевника, являлась его помощником. Образ собаки, сохранившийся в древних легендах, преданиях, сказках, обрядах, приметах и во многих других жанрах фольклора является подтверждением особого отношения к собаке, ее почитания, восприятия как олицетворения символа честности, любви, плодородия и безграничной преданности своему хозяину. Особый статус собаки оттеняется тем, что собака почти не присутствует в сказках о животных, она всегда является спутником и помощником героя-человека. Защитники стад и жилищ кочевников, собаки занимали высокий статус и находились в более привилегированном положении, чем остальные животные. В калмыцком и тувинском фольклоре на создание образа собаки оказало большое влияние буддийская религия, собака почитаема как священное животное, стоявшее на страже трех миров. Она является и воплощением души близких родственников.

Отмечается ряд общих представлений, связанных с собакой и активная роль собаки в представлениях, связанных с детьми и в свадебной обрядности, хотя далеко не все представления, связанные с собакой, с такой исключительной точностью отражаются в фольклоре, как тувинское правило успокаивать собаку при подходе гостя к дому.

\footnotetext{
${ }^{1}$ Хамг әмтнә кел меддг залу күн [“Мужчина, понимавший язык всех живых существ’]. Информант Найминова Б. М., г. Элиста.
} Зап. в 1977 г. Е. Г. Бембеевой. - НА КалмНЦ РАН. Ф. 16. Оп. 1. Кас. № 160 (1), (169). 


\section{СПИСОК ЛИТЕРАТУРЫ}

Бакаева, Э. П. (2010) Добуддийские верования калмыков // Калмыки / отв. ред. Э. П. Бакаева, Н. Л. Жуковская; Ин-т этнологии и антропологии им. Н. Н. Миклухо-Маклая; КИГИ РАН. М. : Наука. 568 с. С. $429-$ 465 .

Басангова, Т. Г. (2007) Обрядовая поэзия калмыков (система жанров, поэтика). Элиста: Калм. кн. издво. 592 с. (На рус. и калм. яз.).

Болдырева, И. М. (2014) Хальмг келн улсин йорлһна тускар ('О калмыцких народных поверьях') // Вестник Калмыцкого института гуманитарных исследований РАН. № 2. С. 91-95.

Бурыкин, А. А. (2001) Малые жанры эвенского фольклора. СПб. : Петербургское востоковедение. 224 c.

Бурятские народные сказки (2008) Волшебные. Бытовые / отв. ред. Л. С. Дампилова. Улан-Удэ : Издво БНЦ СО РАН. 188 с.

Владимирцов, Б. Я. (2003) Работы по литературе монгольских народов. М. : Восточная литература. 608 с.

Герлтсн сувсн (Б. М. Санджиеван бичүлж авсн амн урн үгин көрңгәс). 'Сияющая жемчужина' (Фольклорные материалы, собранные Б. М. Санджиевой’). Собиратель Санджиева Б. М. Записи 1972-1974 гг. (2014) / вступ. ст., сост., предисл., подг. текстов и прилож. И. М. Болдыревой. Элиста : КИГИ РАН. 230 с. (На калм. яз.).

Горяева, Б. Б., Болдырева, И. М. (2017) «Яс кемәлһн» - ‘Сказывание по кости’ в устной традиции калмыков 1960-1970-х гг. // Студент. Аспирант. Исследователь. № 1 (19). С. $79-87$.

Душан, У. (2016) Избранные труды / сост. Батыров В. В., Шараева Т. И. Элиста : КИГИ РАН. 376 с.

Калмыцкие народные сказки (1978) / пер. с калмыцкого. Переизд. Элиста : Калм. кн. изд-во. 146 с.

Козин, С. А. (1941) Сокровенное сказание. Монгольская хроника 1240 г. под названием Mongrol-un niruča tobčiyan. Юань чао би ши : Монг. обыденный сборник. Т. 1. Введение в изучение памятника. Перевод, тексты, глоссарии. М. ; Л. : Изд-во Акад. наук. 620 с.

Манджиева, Б. Б. (2016) Традиционные формулы калмыцкой богатырской сказки и героического эпоса «Джангар» // Филологические науки. Вопросы теории и практики. № 12 (66) : в 4-х ч. Ч. 3. С. 39-42.

Медноволосая девушка. Калмыцкие народные сказки (1964) / пер., сост. и примеч. М. Ватагина. М. : Наука. 263 с.

Митиров, А. Г. (1977) Культура и быт калмыков (этнографические исследования). Элиста : КНИИЯлИ. 113 c.

Мифы народов мира. Энциклопедия (1991) : в 2-х т. / гл. ред. С. А. Токарев. М. : Советская Энциклопедия. Т. 1. А-К (Корейская мифология). 720 с.

Мифы, легенды, предания тувинцев (2010) / отв. ред. В. В. Илларионов. Новосибирск : Наука. 372 с.

Потапов Л. П. (1969) Очерки народного быта тувинцев. М. : Наука, ГРВЛ. 404 с.

Самар, А. П. (2010) Традиционное собаководство нанайцев. Владивосток : Дальнаука. 255 с.

Сандаловый ларец (2002) / составление, перевод, вступительная статья, справочный аппарат Т. Г. Басанговой. Элиста : Калм. кн. изд-во. 239 с.

Серен, П. С. (2015) Собака в семейной обрядности кобдоских тувинцев в Монголии // Природные условия, история и культура Западной Монголии и сопредельных регионов: материалы ХII международной научной конференции (г. Ховд, Монголия, 18-21 сентября). Т. II: Гуманитарные и социальные науки. Ховд; Томск : Национальный исследовательский Томский государственный университет. 206 с. С. $154-154$

Скородумова, Л. Г. (2003) Сказки и мифы Монголии. Улаанбаатар : Монсудар. 141 с.

Таубе, Э. (1994) Сказки и предания алтайских тувинцев. М. : ГРВЛ. 382 с.

Трансграничная культура: Очерки сравнительно-сопоставительного исследования традиций западных монголов и калмыков (2016) / Бакаева, Э. П., Орлова, К. В., Музраева, Д. Н. и др. Элиста : КалмНЦ PAH. 456 c.

Тувинские героические сказания (1997) / отв. ред. В. М. Гацак. Новосибирск : Наука, Сибирское предприятие РАН. 584 с. 
Тувинские народные сказки (1971) / перевод, сост. и прим. М. Ватагина. М. : ГРВЛ. 208 с.

Тувинские народные сказки (1994) / отв. ред. В. М. Гацак. Новосибирск : Наука, Сибирская издательская фирма. 460 с.

Утнасун О. (2015) Б. Х. Тодаеван темдглсн «Ноха мис хойр» домгин тускар ['О дунсянской легенде о собаке и кошке, записанной Б. Х. Тодаевой’] // Монголоведение в начале XXI века: современное состояние и перспективы развития: Мат-лы Междунар. научн. конф., посв. 100-летию Б. Х. Тодаевой (г. Элиста, 23-26 апреля 2015 г.) : в 2-х частях / отв. ред. Н. Г. Очирова. Элиста : КИГИ РАН. Ч. II. 220 с. С. 62-66.

Хальмг үлгүрмүдин болн товчта үгмүдин тәәлвртә толь ('Толковый словарь калмыцких пословиц и поговорок') (2011) / сост. и вступ. ст. У. У. Очирова и Л. С. Сангаева; отв. ред. Э. У. Омакаева. Элиста : ЗАОр «НПП „Джангар“». 224 с.

Юша, Ж. М. (2008) Свадебная обрядность тувинцев: традиции и инновации // Традиции и инновации в современном фольклоре народов Сибири / отв. ред. Г. Е. Солдатова. Новосибирск : Арта. 135 с. C. 52-62.

Boldyreva, I. M. (2015) On kalmyk folk beliefs // Anthropology \& Archeology of Eurasia. T. 53. № 4. Pp. 62-70.

Kalmúckische Sprachproben (1909). Gesammelt und herausgegeben von G. J. Ramstedt. Erster Teil. Kalmúckische Märchen. Helsingfors: Societe Finno-Ougrienne. 154 s.

Дата поступления: 30.08.2019 2.

\section{REFERENCES}

Bakaeva, E. P. (2010) Dobuddiiskie verovaniya kalmykov [Pre-Buddhist beliefs of the Kalmyks]. In: Kalmyki [The Kalmyks]. Ed. by E. P. Bakaeva, N. L. Zhukovskaya. Miklouho-Maclay Institute of Ethnology and Anthropology; Kalmyk Humanities Research Institute of RAS. Moscow, Nauka. 568 p. Pp. 429-465. (In Russ.).

Basangova, T. G. (2007) Obryadovaya poeziya kalmykov (sistema zhanrov, poetika) [Ceremonial poetry of the Kalmyks (system of genres, poetics)]. Elista: Kalm. Book Publ. 592 p. (In Russ. and Kalm.).

Boldyreva, I. M. (2014) Khal'mg keln ulsin iorlyna tuskar [Revisiting Kalmyk folk superstitious beliefs]. Bulletin of the Kalmyk Institute for Humanities of the RAS (Oriental Studies), no. 2, pp. 91-95. (In Russ.).

Burykin, A. A. (2001) Malye zhanry evenskogo fol'klora [Minor genres of Even folklore]. St. Petersburg, Peterburgskoe Vostokovedenie. 224 p. (In Russ.).

Buryatskie narodnye skazki. Volshebnye. Bytovye [Buryat folk tales: magic and household ones] (2008). Ed. by L. S. Dampilova. Ulan-Ude, Buryat Scientific Center (Siberian Branch) of RAS. 188 p. (In Russ.).

Vladimirtsov, B. Ya. (2003) Raboty po literature mongol'skikh narodov [Works on literatures of Mongolic peoples]. Moscow, Vostochnaya Literatura. 608 p. (In Russ.).

Gerltsn suvsn (B. M. Sandzhievan bichülj avsn amn urn ügin körngäs) [The Glistering Pearl: folklore materials collected by B. M. Sandzhieva] (2014). Coll. by B. M. Sandzhieva. Recordings of 1972-1974. Introduction, comp., foreword., preparation of texts and suppl. by I. M. Boldyreva. Elista, Kalmyk Humanities Research Institute of RAS. 230 p. (In Kalm.).

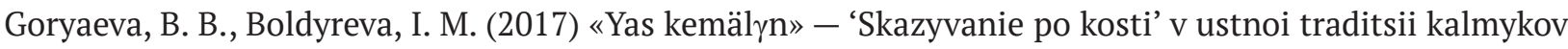
1960-1970-kh gg. ['Bone divination narratives' in the oral tradition of the Kalmyks: 1960s - 1970s]. Student. Aspirant. Issledovatel', no. 1 (19), pp. 79-87. (In Russ.).

Dushan, U. (2016) Izbrannye Trudy [Selected works]. Comp. by Batyrov V. V., Sharaeva T. I. Elista, Kalmyk Humanities Research Institute of RAS. 376 p. (In Russ.).

Kalmytskie narodnye skazki [Kalmyk folk tales] (1978). Transl. from Kalmyk. Reprint. Elista, Kalm. Book Publ. 146 p. (In Russ.).

Kozin, S. A. (1941) Sokrovennoe skazanie. Mongol'skaya khronika 1240 g. pod nazvaniem [The Secret History of the Mongols: a 1240 Mongolian chronicle titled 'Mongyol-un nizuča tobčiyan. Yuan' chao bi shi']. A Mongolian mundane collection. Vol. 1: Introduction to studies of the monument. Translation, texts, glossaries. Moscow, Leningrad, USSR Academy of Sciences. 620 p. (In Russ.).

Mandzhieva, B. B. (2016) Traditsionnye formuly kalmytskoi bogatyrskoi skazki i geroicheskogo eposa «Dzhangar» [Traditional formulas of the Kalmyk heroic tale and heroic epos 'Dzhangar']. Philological Sciences. Issues of Theory and Practice, no. 12 (66 / in 4 vols.), vol. 3, pp. 39-42. (In Russ.).

Mednovolosaya devushka. Kalmytskie narodnye skazki [The Copper-Haired Girl: Kalmyk folk tales] (1964). Transl., comp. and comment. by M. Vatagin. Moscow, Nauka. 263 p. (In Russ.). 
Mitirov, A. G. (1977) Kul'tura i byt kalmykov (etnograficheskie issledovaniya) [Culture and everyday life of the Kalmyks (ethnographic studies)]. Elista, KNIIYaLI. 113 p. (In Russ.).

Mify narodov mira. Entsiklopediya [Myths of the world. Encyclopedia] (1991). In 2 vols. Ed. by S. A. Tokarev. Moscow, Sovetskaya Entsiklopediya. Vol. 1: 'A-K' (Korean mythology). 720 p. (In Russ.).

Mify, legendy, predaniya tuvintsev [Myths, legends and tales of the Tuvans] (2010). Ed. by V. V. Illarionov. Novosibirsk, Nauka. 372 p. (In Russ.).

Potapov L. P. (1969) Ocherki narodnogo byta tuvintsev [The Tuvans: sketches of folk lifestyles]. Moscow, Nauka, GRVL. 404 p. (In Russ.).

Samar, A. P. (2010) Traditsionnoe sobakovodstvo nanaitsev [Traditional dog breeding of the Nanai people]. Vladivostok, Dalnauka. 255 p. (In Russ.).

Sandalovyi larets [The Sandalwood Chest] (2002). Comp., transl., introduction, postlims by T. G. Basangova. Elista, Kalm. Book Publ. 239 p. (In Russ.).

Seren, P. S. (2015) Sobaka v semeinoi obryadnosti kobdoskikh tuvintsev v Mongolii [The dog in family rites of Khovd Tuvans, Mongolia]. In: Prirodnye usloviya, istoriya i kul'tura Zapadnoi Mongolii i sopredel'nykh regionov [Western Mongolia and adjacent regions: natural conditions, history and culture]. Proceedings of the $12^{\text {th }}$ international scientific conference (Khovd, Mongoliya, September 18-21). Vol. II: Humanities and social sciences. Khovd; Tomsk, National Research Tomsk State University. 206 p. Pp. 154-154. (In Russ.).

Skorodumova, L. G. (2003) Skazki i mify Mongolii [Tales and myths of Mongolia]. Ulaanbaatar, Monsudar. 141 p. (In Russ.).

Taube, E. (1994) Skazki i predaniya altaiskikh tuvintsev [Tales and legends of the Altaian Tuvans]. Moscow, Nauka, GRVL. 382 p. (In Russ.).

Transgranichnaya kul'tura: Ocherki sravnitel'no-sopostavitel'nogo issledovaniya traditsii zapadnykh mongolov i kalmykov [Cross-border culture: comparative research sketches of traditions of the western Mongols and Kalmyks] (2016). E. P. Bakaeva et al. Elista, Kalmyk Scientific Center of RAS. 456 p. (In Russ.).

Tuvinskie geroicheskie skazaniya [Tuvan heroic tales] (1997). Ed. by V. M. Gatsak. Novosibirsk, Nauka. 584 p. (In Russ.).

Tuvinskie narodnye skazki [Tuvan folk tales] (1971). Transl., comp. and comment. by M. Vatagin. Moscow, Nauka, GRVL. 208 p. (In Russ.).

Tuvinskie narodnye skazki [Tuvan folk tales] (1994). Ed. by V. M. Gatsak. Novosibirsk, Nauka. 460 p. (In Russ.).

Utnasun O. (2015) B. Kh. Todaevan temdglsn «Nokha mis khoir» domgin tuskar [Revisiting The Tale of the Dog and the Cat recorded by B. Kh. Todaeva]. In: Mongolovedenie v nachale XXI veka: sovremennoe sostoyanie $i$ perspektivy razvitiya [Mongol studies in the early $21^{\text {st }}$ century: current state and development prospects]. Proceedings of the international scientific conference commemorating the $100^{\text {th }}$ anniversary of Prof. B. Kh. Todaeva (Elista, April 23-26, 2015). In 2 vols. Ed. by N. G. Ochirova. Elista, Kalmyk Humanities Research Institute of RAS. Vol. II. 220 p. Pp. 62-66. (In Russ.).

Khal'mg ülgürmüdin boln tovchta ügmüdin täälvrtə tol' [Explanatory dictionary of Kalmyk proverbs and sayings] (2011). Comp. and foreword by U. U. Ochirov and L. S. Sangaev; ed. by E. U. Omakaeva. Elista, Dzhangar. 224 p. (In Russ.).

Yusha, Zh. M. (2008) Svadebnaya obryadnost' tuvintsev: traditsii i innovatsii [Wedding rites of the Tuvans: traditions and novelties]. In: Traditsii i innovatsii v sovremennom fol'klore narodov Sibiri [Traditions and novelties in contemporary folklore of Siberia's nations]. Ed. by G. E. Soldatova. Novosibirsk, Arta. 135 p. Pp. 52-62. (In Russ.).

Boldyreva, I. M. (2015) On Kalmyk folk beliefs. Anthropology \& Archeology of Eurasia, vol. 53, no. 4, pp. 62-70.

Kalmückische Sprachproben [Kalmyk speech patterns] (1909). Coll. and publ. by G. J. Ramstedt. Part 1. Kalmyk fairy tales. Helsinki, Finno-Ugric Society. 154 p. (In Germ.).

Submission date: 30.08 .2019 . 